\title{
Method of Preparation for High-Purity Nanocrystalline Anhydrous Cesium Perrhenate
}

\author{
Katarzyna Leszczyńska-Sejda *, Grzegorz Benke, Mateusz Ciszewski, Joanna Malarz and \\ Michał Drzazga \\ Institute of Non Ferrous Metals, Hydrometallurgy Department, ul. Sowińskiego 5, 44-100 Gliwice, Poland; \\ grzegorzb@imn.gliwice.pl (G.B.); mateuszc@imn.gliwice.pl (M.C.); joannam@imn.gliwice.pl (J.M.); \\ michald@imn.gliwice.pl (M.D.) \\ * Correspondence: kasial@imn.gliwice.pl; Tel.: +48-32-238-06-57; Fax: +48-32-231-69-33
}

Academic Editor: Hugo F. Lopez

Received: 23 December 2016; Accepted: 9 March 2017; Published: 15 March 2017

\begin{abstract}
This paper is devoted to the preparation of high-purity anhydrous nanocrystalline cesium perrhenate, which is applied in catalyst preparation. It was found that anhydrous cesium perrhenate with a crystal size $<45 \mathrm{~nm}$ can be obtained using cesium ion sorption and elution using aqueous solutions of perrhenic acid with subsequent crystallisation, purification, and drying. The following composition of the as-obtained product was reported: $34.7 \% \mathrm{Cs} ; 48.6 \%$ Re and $<2 \mathrm{ppm} \mathrm{Bi} ;<3 \mathrm{ppm} \mathrm{Zn}$; $<2$ ppm As; $<10$ ppm Ni; $<3$ ppm Mg; $<5$ ppm Cu; $<5$ ppm Mo; $<5$ ppm Pb; $<10$ ppm K; $<2$ ppm Na; $<5$ ppm Ca; $<3$ ppm Fe.
\end{abstract}

Keywords: cesium; caesium; rhenium; perrhenate; cation resin

\section{Introduction}

Both cesium and rhenium are classified as rare metals with naturally occurring deposits scattered around the world [1,2]. Molybdenites from porphyry copper deposits are the most important rhenium sources, while cesium can be mainly found in pollucite $\left(\mathrm{CsAlSi}_{2} \mathrm{O}_{6}\right)$ [1-3]. Rhenium can be characterised by a high melting temperature $(3453 \mathrm{~K})$ and high density $\left(21.0 \mathrm{~g} / \mathrm{cm}^{3}\right)$. It can be used in organic and inorganic chemistry, catalysis, and pharmacy [1,3]. Recently, it has been used as an alloy and superalloy additive, while ${ }^{186}$ Re and ${ }^{188}$ Re isotopes have been found in radiotherapy [2]. It is catalytically active in hydrogenation and dehydrogenation reactions. It can be used in either heterogeneous or homogenous catalysis of numerous other organic reactions [4,5]. Platinum-rhenium catalysts are used in the petrochemical industry in high-octane petrol production [1]. On the contrary, cesium is soft and one of the most reactive metals, and due to its strong photoelectric effect, is mainly used in photocell production. It may also be found in infrared radiation sensors, organic synthesis, and hydrogenation reaction catalysts. The ${ }^{137} \mathrm{Cs}$ isotope is used in cancer treatment.

Synthesis, properties, and applications of cesium perrhenate are poorly described. In the past, $\mathrm{CsReO}_{4}$ was mainly synthesised to define its physicochemical properties [6]. According to these sources, cesium perrhenate can be obtained by neutralisation of perrhenic acid aqueous solution in the presence of cesium carbonate or hydroxide [7-11], as well as by reaction of sodium perrhenate aqueous solution with cesium chloride $[12,13]$ and by reaction of cesium hydroxide with ammonium perrhenate $[14,15]$. It was also reported that cesium perrhenate can be used in the synthesis of heterogenous rhenium-cesium catalyst $[16,17]$. The ion-exchange technique is applied, for example, to nickel(II) and cobalt(II) perrhenate production [18]. There are also reports concerning cesium recovery from nuclear wastewater using different sorbents [19-24].

This paper presents the synthesis of high-purity anhydrous nanocrystalline cesium perrhenate, which can be used as a substrate in the preparation of organic and inorganic rhenium compounds, 
including rhenium catalysts (e.g., methyltrioxorhenium (MTO), rhenium carbonyl $\left(\operatorname{Re}_{2}(C O)_{10}\right)$ and its derivatives), as well as heterogeneous catalysts containing rhenium and cesium additives (e.g., $\mathrm{Al}_{2} \mathrm{O}_{3}$ or $\mathrm{SiO}_{2}$-based. It should be noted that, currently, at the large-laboratory scale, MTO is manufactured from silver perrhenate, while $\operatorname{Re}_{2}(\mathrm{CO})_{10}$ is manufactured from ammonium perrhenate $[25,26]$. Cesium perrhenate has similar properties to silver and ammonium perrhenates and, therefore, it may be applied in MTO and $\mathrm{Re}_{2}(\mathrm{CO})_{10}$ synthesis. The important benefits of $\mathrm{CsReO}_{4}$ application may be: reaction yield increase, reaction time shortening, and selection of more environmentally friendly solvents.

There are also reports on heterogenous rhenium catalysts doped with cesium. Currently, these catalysts are prepared using aqueous ammonium perrhenate solution as the rhenium source and aqueous cesium nitrate solution as a source of cesium [27]. Replacing these solutions by a single aqueous cesium perrhenate solution may result in: uniform migration of the solution in catalyst support, easier catalyst preparation, and no need to eliminate unnecessary components, like nitrate and ammonium ions.

Currently, only the nuclear industry uses cesium perrhenate on a large scale [28].

\section{Experimental Section}

\subsection{Materials}

High-purity perrhenic acid, prepared in the Institute of Non-Ferrous Metals (IMN) in Gliwice using the ion-exchange method, was used as a rhenium source [29-31]. Its chemical composition was as follows: $100.0 \mathrm{~g} / \mathrm{dm}^{3}$ Re and $<20 \mathrm{ppm}$ ammonium ions and $<2 \mathrm{ppm} \mathrm{As} ;<2 \mathrm{ppm} \mathrm{Bi},<3 \mathrm{ppm} \mathrm{Zn}$, $<3 \mathrm{ppm} \mathrm{Mg},<3 \mathrm{ppm} \mathrm{Cu},<5$ ppm Mo, $<5$ ppm Ni, $<5 \mathrm{ppm} \mathrm{Pb},<10 \mathrm{ppm} \mathrm{K},<3 \mathrm{ppm} \mathrm{Ca},<3$ ppm Fe, $<3$ ppm Al, $<5$ ppm Co [10-12]. Cesium nitrate(V) from Alfa Aesar (Chemat, Gdańsk, Poland) was used as a cesium source. Strongly acidic hydrogenated cation-exchange resins (C160, PFC100, CT169 from Purolite (Gdynia, Poland) and S100, SP112 from Bayer Chemicals (ChemTech, Warsaw, Poland) were examined. Double-distilled water with a specific conductivity of $<2 \mu \mathrm{S} / \mathrm{cm}, 30 \%$ hydrogen peroxide solution (Merck, Warsaw, Poland), and acetone (Sigma Aldrich, Poznań, Poland) were used.

\subsection{Cesium Perrhenate Preparation-Ion Exchange}

A new method of anhydrous nanocrystalline cesium perrhenate synthesis, an alternative to the classical one, was developed. It is composed of two stages: sorption of $\mathrm{Cs}^{+}$ions and their elution by aqueous solution of perrhenic acid:

$$
\begin{aligned}
& \text { sorption: [cationite]- } \mathrm{H}^{+}+\mathrm{Cs}^{+} \rightarrow\left[\text { cationite]-Cs }{ }^{+}+\mathrm{H}^{+}\right. \\
& \text {elution: [cationite]-Cs }{ }^{+}+\mathrm{HReO}_{4} \rightarrow\left[\text { cationite]- } \mathrm{H}^{+}+\mathrm{CsReO}_{4}\right.
\end{aligned}
$$

Tests were performed in static and dynamic conditions. Preliminary experiments at static conditions allowed the choice of the best-fitted cationite for $\mathrm{Cs}^{+}$sorption. Then, in further static tests, the effect of selected parameters (temperature, contact time of a solution with ion-exchange resin, and cesium concentration in an initial solution) on $\mathrm{Cs}^{+}$sorption efficiency of resins was determined. Ion-exchange selection was carried out using the following procedure: $10.0 \mathrm{~g}$ of ion-exchange resin was mixed for $30 \mathrm{~min}$ at ambient temperature with $100 \mathrm{~cm}^{3}$ of cesium nitrate(V) aqueous solution containing $5.0 \mathrm{~g} / \mathrm{dm}^{3} \mathrm{Cs}$ and followed by vacuum filtration. Solutions were analysed to estimate cesium content. Cesium sorption efficiency was calculated using the following formula:

$$
W_{C s}=\frac{m_{0 C s}-C_{C s} V}{m_{0 C s}} \times 100 \%
$$

where: $m_{0 C s}$ is the cesium mass in a solution before sorption $(\mathrm{g}) ; C_{C s}$ is the cesium concentration in a solution after sorption $\left(\mathrm{g} / \mathrm{dm}^{3}\right)$; and $V$ is the volume of the solution after sorption $\left(\mathrm{dm}^{3}\right)$. 
The effect of temperature, contact time, and cesium concentration of an initial solution on cesium sorption efficiency was conducted in the same conditions as presented for ion-exchange selection. The examined temperature was in the range 293-333 K, with a contact time of 30-120 min, and a cesium concentration of $0.5-20.0 \mathrm{~g} / \mathrm{dm}^{3}$. The effect of contact time and cesium concentration on sorption efficiency was examined at ambient temperature, while the effect of cesium concentration was examined for a contact time of $60 \mathrm{~min}$.

In the next stage, the influence of contact time, temperature, and rhenium-cesium ratio on Cs elution was determined. Ion-exchange resins after the sorption stage contained: C160: $4.6 \%$ Cs; PFC100: 4.5\% Cs; CT169: 4.7\% Cs. The procedure was as follows: $5.0 \mathrm{~g}$ of ion-exchange resin containing sorbed cesium was magnetically mixed with $10 \mathrm{~cm}^{3}$ perrhenic acid of concentration $100.0 \mathrm{~g} / \mathrm{dm}^{3}$ Re. Solutions were mixed for $30 \mathrm{~min}$, and vacuum filtered. Then, cesium content was analysed. The following parameter ranges were examined: contact time 30-180 min, temperature 293-333 K, and rhenium-to-cesium ratio 5:1-30:1. Contact time of $60 \mathrm{~min}$ was used to examine the effect of temperature and Re:Cs ratio. Elution efficiency was calculated using the formula:

$$
W_{C S}^{\prime}=\frac{C^{\prime}{ }_{C S} V^{\prime}}{m_{0 C S}^{\prime}-C^{\prime}{ }_{C S} V^{\prime}} \times 100 \%
$$

where: $m^{\prime}{ }_{0 C S}$ is the cesium mass in a solution before elution $(\mathrm{g}) ; C^{\prime}{ }_{C S}$ is the cesium concentration in a solution after elution $\left(\mathrm{g} / \mathrm{dm}^{3}\right)$; and $V^{\prime}$ is the volume of solution after elution $\left(\mathrm{dm}^{3}\right)$.

Dynamic tests were carried out according to the following procedure: $100 \mathrm{~cm}^{3}$ CT169 or C160 ion-exchange resins were placed in a column $2.5 \mathrm{~cm}$ in diameter. Then, a cesium nitrate $(\mathrm{V})$ solution containing $5.0 \mathrm{~g} / \mathrm{dm}^{3} \mathrm{Cs}$ was added until the cesium concentration in the effluent reached the initial level. The effluent solution was separated into three portions of $100 \mathrm{~cm}^{3}$ and analysed for cesium content. After, the sorption ion-exchange resin was washed with distilled water until pH 7.0 was reached. Then, $600 \mathrm{~cm}^{3}$ perrhenic acid at a concentration of $100 \mathrm{~g} \mathrm{Re} / \mathrm{dm}^{3}$ was passed up the column. Ion-exchange resin was washed until neutral $\mathrm{pH}$ was reached and used in the next process.

Solutions from elution and the first portion of washing solutions (containing $1.0 \mathrm{~g} / \mathrm{dm}^{3} \mathrm{Cs}$ ) were concentrated. Three operation cycles were performed in this way. The succeeding data were evaluated: cesium ion sorption efficiency: Equation (1), cesium ion elution efficiency: Equation (2), ion-exchange saturation by cesium ions in each stage: Equation (3); $\mathrm{OZ}_{1}$ : bed volume for which cesium concentration is $<0.01 \mathrm{~g} / \mathrm{dm}^{3} ; \mathrm{OZ}_{2}$ : bed volume when the column is totally filled; $\mathrm{OZ}_{3}$ : bed volume when cesium concentration is higher than $5.0 \mathrm{~g} / \mathrm{dm}^{3}$, for elution; $\mathrm{OZ}_{4}$ : bed volume when cesium concentration is higher than $1.0 \mathrm{~g} / \mathrm{dm}^{3}$, for elution and washing after elution.

$$
S_{C s}=\frac{m_{0 C s}-C_{C s} V}{m_{J}} \times 100 \%
$$

where: $m_{0 C s}$ is the cesium mass in a solution before sorption $(\mathrm{g}) ; m_{J}$ is the mass of ion-exchange resin $\left(\mathrm{cm}^{3}\right) ; C_{C s}$ is the cesium concentration in solution after sorption $\left(\mathrm{g} / \mathrm{dm}^{3}\right)$; and $V$ is the volume of solution after sorption $\left(\mathrm{dm}^{3}\right)$.

Solutions from elution and washing after elution were combined in such a way as to obtain different cesium concentrations, namely 3,5, and $10 \mathrm{~g} / \mathrm{dm}^{3}$ in a concentration stage. The volume of solutions directed to crystallisation was constant and equal to $1.5 \mathrm{dm}^{3}$. Concentrated solutions were intensively mixed at temperatures up to $353 \mathrm{~K}$. Then, solutions were cooled at $0.5 \mathrm{~K} / \mathrm{min}$ until ambient temperature. Crystallised cesium perrhenate was separated from solutions by filtration. Additionally, cesium perrhenate prepared using $10 \mathrm{~g} / \mathrm{dm}^{3} \mathrm{Cs}$ solution was divided into five parts and directed to the purification stage. The purification process was a single- or two-step washing of filtered crystals. The washing media were $50 \mathrm{~cm}^{3}$ portions of $5 \%$ or $10 \%$ aqueous hydrogen peroxide solutions and/or $20 \mathrm{~cm}^{3}$ portions of anhydrous acetone. Purified crystals were dried at $393 \mathrm{~K}$ until constant mass. Cesium and rhenium content, as well as selected contaminations (i.e., As, $\mathrm{Cu}, \mathrm{Zn}, \mathrm{Ca}, \mathrm{Fe}, \mathrm{Mo}, \mathrm{Ni}, \mathrm{Pb}$, $\mathrm{Na}, \mathrm{K}, \mathrm{Mg}, \mathrm{Bi}$ ) were analysed and the crystallite size was evaluated. 


\subsection{Characterisation}

All necessary analyses were performed in the Department of Analytical Chemistry at the Institute of Non-Ferrous Metals in Gliwice. Base element ( $\mathrm{Re}, \mathrm{Cs}$ ) content was determined in obtained cesium perrhenates. A weight method using tetraphenylarsenic chloride (CTFA) as the precipitating agent was used to evaluate rhenium content and flame atomic emission spectroscopy (FAES, spectrophotometer AAS novAA400) for cesium content. In order to determine $\mathrm{As}, \mathrm{Cu}, \mathrm{Zn}, \mathrm{Ca}, \mathrm{Fe}, \mathrm{Mo}, \mathrm{Ni}, \mathrm{Pb}, \mathrm{Na}$, $\mathrm{K}, \mathrm{Mg}, \mathrm{Bi}$ content, different techniques were used: GFAAS (graphite furnace atomic absorption spectroscopy with graphite cells, Z-2000, HITACHI), ICP-OES (inductively coupled plasma-optical emission spectrometer, ULTIMA 2, HORIBA Jobin-Ivon), and ICP-MS (inductively coupled plasma mass spectrometry, ICP MS NexION). Solutions were analysed to evaluate rhenium and cesium content by FAAS (flame atomic absorption spectroscopy equipped with flame module and deuter background correction, SOLAAR S4, THERMO). X-ray diffraction analysis was performed using Co K $\alpha$ radiation and an Fe filter (XRD 7, Seifert-FPM). Based on the XRD pattern, the crystallite size was calculated using the Scherrer method without accounting for stresses. Crystallite size can be calculated using the formula:

$$
L=\frac{K \lambda}{B(2 \theta) \cos \theta}
$$

where: $L$ is the crystallite size, $K$ is the shape factor ca. 0.9 if crystallites are spherical, $\lambda$ is the $X$-ray wavelength, $\theta$ is Bragg's angle, and $B(2 \theta)$ is the line-broadening at half-maximum.

\section{Results and Discussion}

\subsection{Ion-Exchange Resin Selection-Sorption Stage}

In the preliminary experiments concerning ion-exchange resin selection, it was found that all materials had above $65.0 \%$ efficiency of cesium ion sorption. The highest values were recorded for PFC100 and C160-above 90.0\% cesium sorption. Results are presented in Table 1. CT169, C160, and PFC100 were selected for further investigations.

Table 1. Results of ion-exchange resin selection for cesium sorption.

\begin{tabular}{cccc}
\hline Ion-Exchange Resin & $\begin{array}{c}\text { Volume of a Solution } \\
\text { after Sorption }\end{array}$ & $\begin{array}{c}\text { Cs Concentration in a } \\
\text { Solution after Sorption }\end{array}$ & $\begin{array}{c}\text { Cs }^{+} \text {Sorption Efficiency } \\
\text { (cm }\end{array}$ \\
\hline S100 & 110 & 1.3 & \% \\
SP112 & 115 & 1.4 & 71.4 \\
PFC100 & 125 & 0.4 & 67.8 \\
CT169 & 120 & 0.3 & 90.0 \\
C160 & 125 & 0.3 & 92.8 \\
\hline
\end{tabular}

\subsection{Influence of Temperature on Cesium Ion Sorption Efficiency}

No influence of this parameter on sorption was observed for C160 ion-exchange resin. For the other materials, a slight sorption increase with increasing temperature was observed. Due to that observation, and the lower stability of ion exchange resins at elevated temperatures, all tests were performed at ambient temperature. The results are presented in Table 2. 
Table 2. Results of the effect of temperature on cesium ion sorption efficiency.

\begin{tabular}{ccccc}
\hline $\begin{array}{c}\text { Ion Exchange } \\
\text { Resin }\end{array}$ & Temperature & $\begin{array}{c}\text { Volume of a Solution } \\
\text { after Sorption }\end{array}$ & $\begin{array}{c}\text { Cs Concentration in a } \\
\text { Solution after Sorption }\end{array}$ & $\begin{array}{c}\mathbf{C s}^{+} \text {Sorption } \\
\text { Efficiency }\end{array}$ \\
\hline K & $\mathbf{c m}^{\mathbf{3}}$ & $\mathbf{g} / \mathbf{c m}^{\mathbf{3}}$ & $\mathbf{\%}$ \\
\hline \multirow{2}{*}{ C160 } & 293 & 125 & 0.3 & 92.5 \\
& 313 & 120 & 0.3 & 92.8 \\
& 333 & 125 & 0.3 & 92.5 \\
\hline \multirow{2}{*}{ CT169 } & 293 & 120 & 0.3 & 92.8 \\
& 313 & 120 & 0.1 & 97.6 \\
PFC100 & 333 & 126 & 0.1 & 97.5 \\
& 293 & 125 & 0.4 & 90.0 \\
& 313 & 120 & 0.2 & 95.2 \\
\end{tabular}

\subsection{Influence of Contact Time on Cesium Ion Sorption Efficiency}

No influence of contact time on cesium ion sorption efficiency was found for C160 ion-exchange resin while, for PFC100 and CT169, a significant increase was observed for longer contact times. Therefore, $60 \mathrm{~min}$ was selected as a required contact time for further static measurements. Results are presented in Figure 1.

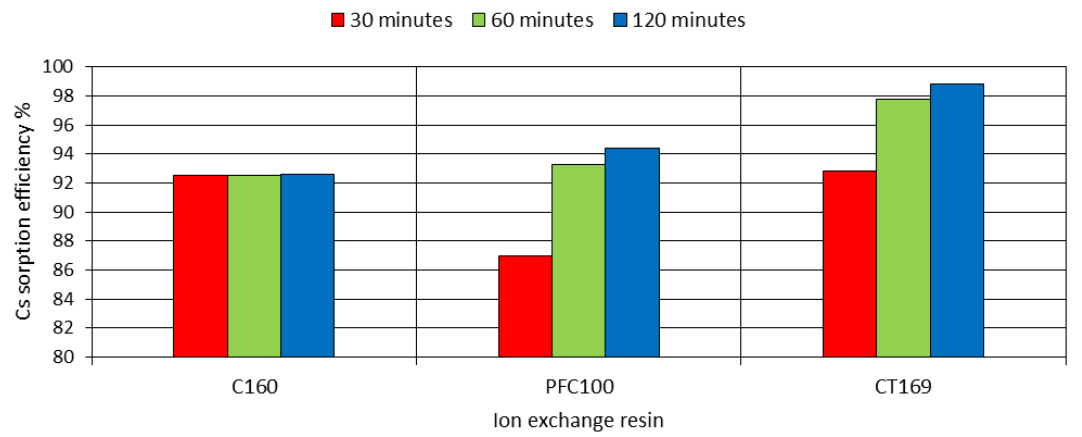

Figure 1. Influence of contact time on cesium ion sorption efficiency.

\subsection{Influence of Cesium Concentration on Cesium Ion Sorption Efficiency}

Cesium concentration in nitrate $(V)$ solutions before sorption was in the range $0.5-20.0 \mathrm{~g} / \mathrm{dm}^{3}$. It was found that, for CT169, efficiency of cesium ions was $99 \%$ when a solution of concentration $5.0 \mathrm{~g} / \mathrm{dm}^{3}$ was used. Additionally, C160 and PFC100 had slightly lower cesium sorption efficiencies. For cesium concentration higher than $5.0 \mathrm{~g} / \mathrm{dm}^{3}$, about $90 \%$ sorption efficiency was observed, regardless of the type of ion-exchange resin. The results are presented in Figure 2.

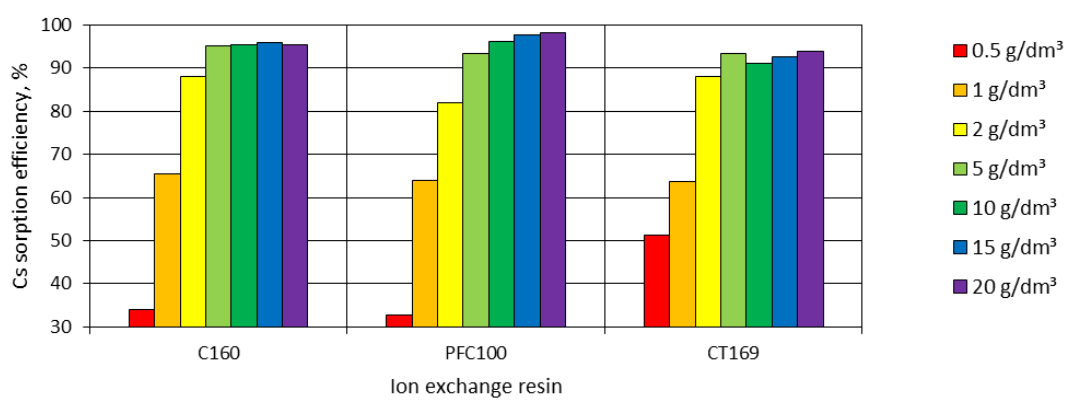

Figure 2. Influence of cesium concentration on cesium ion sorption efficiency. 


\subsection{Ion-Exchange Selection-Elution Stage}

Elution tests allowed the distinguishing and selection of the best appropriate ion-exchange resins. A high value of cesium ion elution was observed for C160 and CT169. It should be noted that these resins had high stability and appropriate sorption parameters. These materials were chosen for further experiments to perform cesium ion elution tests. The results are presented in Table 3.

Table 3. Results of ion-exchange resin selection for cesium sorption.

\begin{tabular}{cccc}
\hline Ion-Exchange Resin & Volume of a Solution & $\begin{array}{c}\text { Cs Concentration in a } \\
\text { Solution after Elution }\end{array}$ & Cs $^{+}$Elution Efficiency \\
\hline & $\mathbf{c m}^{\mathbf{3}}$ & $\mathbf{g} / \mathbf{c m}^{\mathbf{3}}$ & $\%$ \\
\hline C160 & 25 & 8.1 & 88.0 \\
CT169 & 24 & 9.4 & 96.0 \\
PFC100 & 25 & 4.5 & 50.0 \\
\hline
\end{tabular}

\subsection{Influence of Contact Time vs. Elution Efficiency}

It was established that cesium ion elution efficiency slightly increased with increase of contact time. The time of $60 \mathrm{~min}$ was assumed to be optimal for further research. Results are presented in Figure 3.

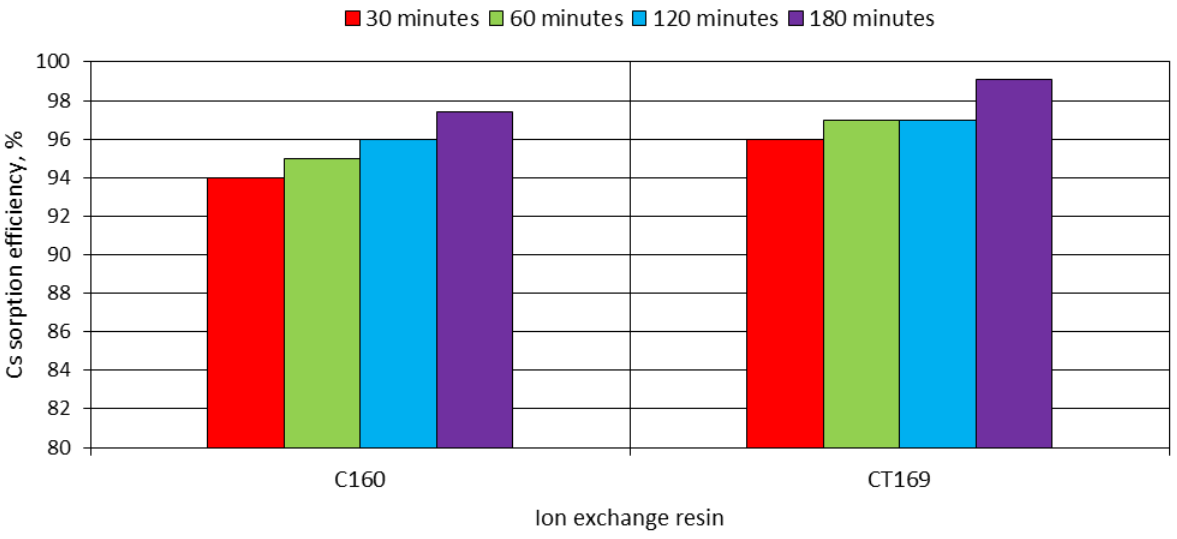

Figure 3. Influence of contact time on cesium ion elution efficiency.

\subsection{Influence of Temperature on Cesium Ion Elution Efficiency}

No temperature influence on elution efficiency for CT169 and C160 was observed. Results are presented in Table 4.

Table 4. Influence of temperature on cesium ions elution efficiency.

\begin{tabular}{ccccc}
\hline $\begin{array}{c}\text { Ion-Exchange } \\
\text { Resin }\end{array}$ & Temperature & Volume of a Solution & $\begin{array}{c}\text { Cs Concentration in a } \\
\text { Solution after Elution }\end{array}$ & $\begin{array}{c}\text { Cs }^{+} \text {Sorption } \\
\text { Efficiency }\end{array}$ \\
\hline & $\mathbf{K}$ & $\mathbf{c m}^{\mathbf{3}}$ & $\mathbf{g} / \mathbf{c m}^{\mathbf{3}}$ & $\mathbf{\%}$ \\
\hline \multirow{3}{*}{ CT169 } & 293 & 24 & 9.5 & 97.0 \\
& 313 & 24 & 9.4 & 96.0 \\
& 333 & 24 & 9.5 & 97.0 \\
\hline & 293 & 24 & 9.3 & 97.0 \\
C160 & 313 & 23 & 9.8 & 98.0 \\
& 333 & 23 & 9.8 & 98.0 \\
\hline
\end{tabular}




\subsection{Influence of Rhenium-to-Cesium Ratio on Cesium Ion Elution Efficiency}

The rhenium-to cesium ratio increase in a solution enhances $\mathrm{Cs}^{+}$ion elution efficiency. It was found that at least a 10 times excess of rhenium with respect to cesium was required to exceed $90 \%$ cesium elution efficiency for CT169 resin. In the case of C160, the highest elution efficiency (92\%) was reported for a rhenium-to-cesium ratio 30:1. Results are presented in Figure 4. CT169 was chosen as the best resin and it was used in dynamic tests.

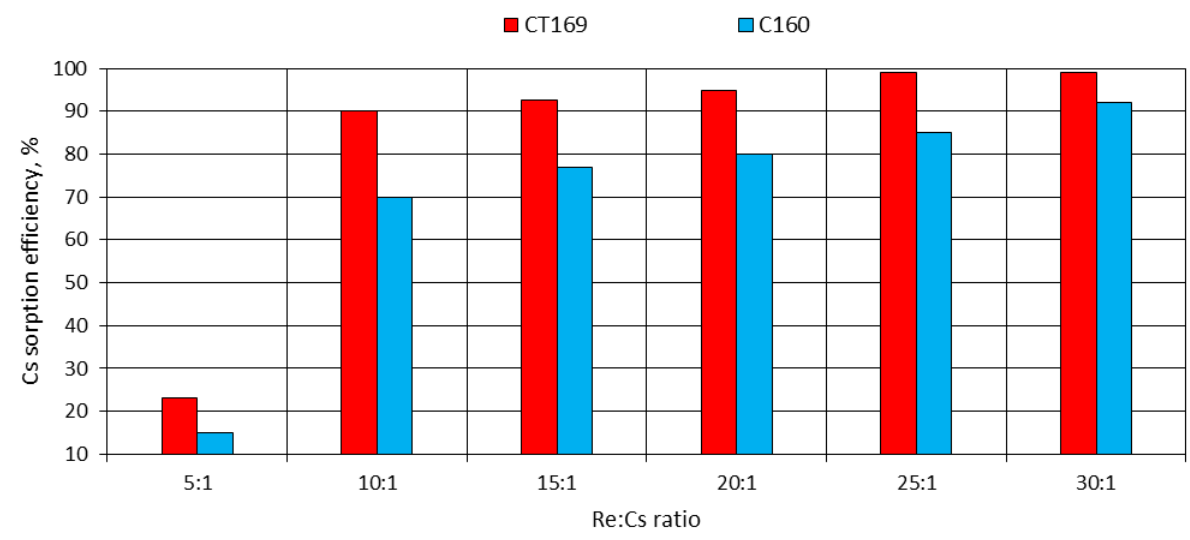

Figure 4. Influence of rhenium-to-cesium ratio on cesium ion elution efficiency.

\subsection{Analysis of Three Cycles of CT169 in Dynamic Conditions}

Sorption and elution tests of cesium ions allowed the determination of CT169 as the most appropriate resin for this purpose. Based on these results, optimum process parameters for dynamic tests were presented. Three operation cycles were performed using CT169. Results of cesium ion sorption are presented in Figure 5 and Table 5, while elution results are shown in Figure 6 and Table 6. High and stable sorption parameters, $75 \%-70 \%$ sorption efficiency and $4.5 \%-4.6 \%$ ion-exchange saturation, by cesium ions were obtained. Elution was very effective with an efficiency significantly above $95.0 \%$ in all cycles. It should be pointed out that a slight increase in the efficiency was observed in subsequent cycles, which indicates proper operation of the ion-exchange resin.

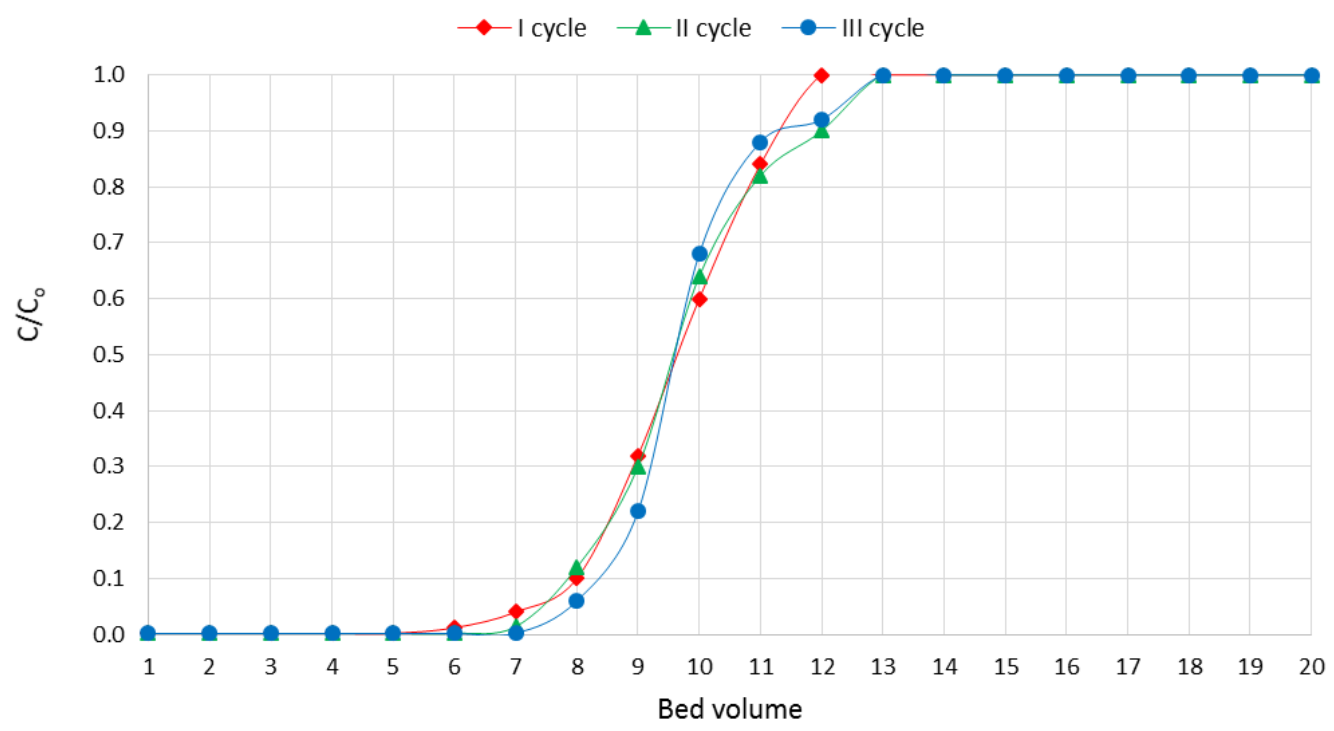

Figure 5. Characteristics of CT169 during sorption. 


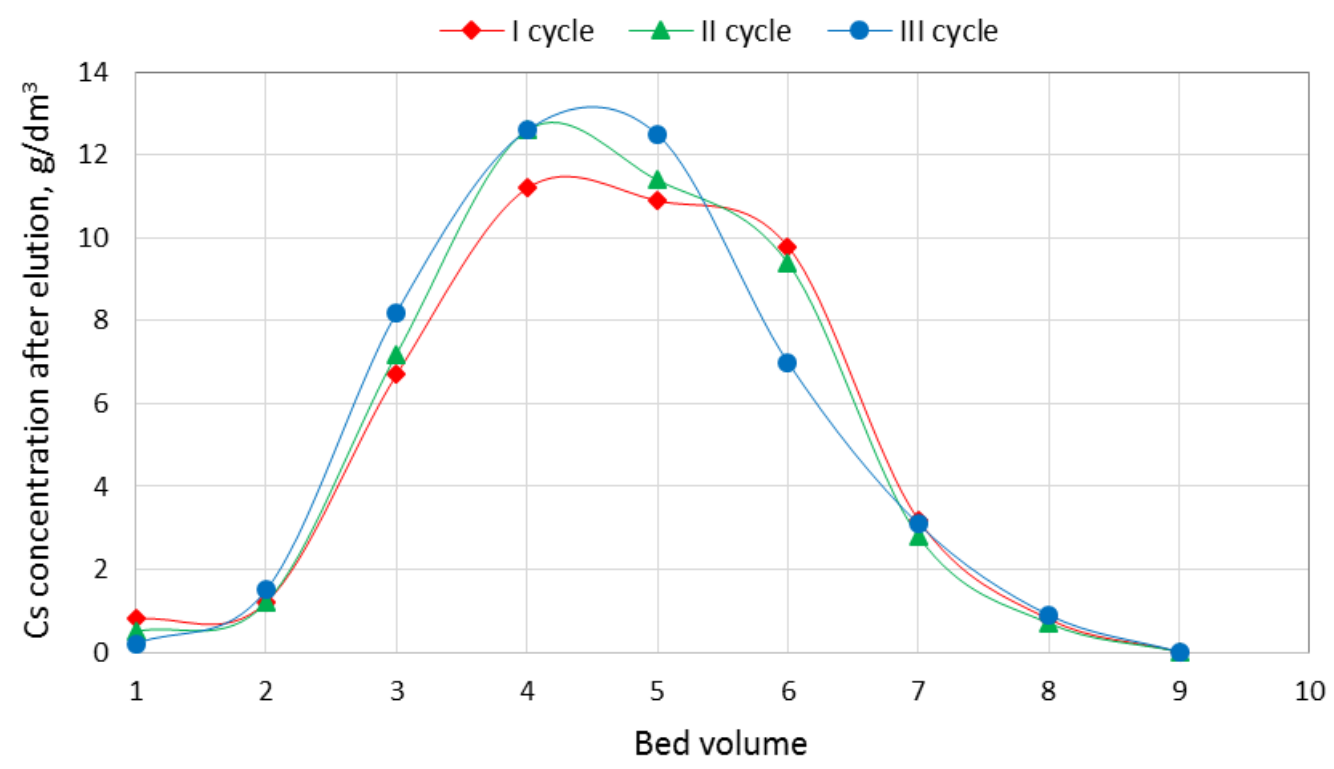

Figure 6. Characteristics of CT169 during elution.

Table 5. Parameters for cesium ion sorption-CT169.

\begin{tabular}{ccccc}
\hline Cycle No. & $\mathbf{O Z}_{\mathbf{1}}$ & $\mathbf{O Z}_{\mathbf{2}}$ & $\boldsymbol{W}_{\mathrm{Cs}} \boldsymbol{\gamma} \%$ & $\boldsymbol{S}_{\mathrm{Cs}} \boldsymbol{\%} \%$ \\
\hline I & 5 & 12 & 75.6 & 4.5 \\
II & 6 & 13 & 70.7 & 4.6 \\
III & 6 & 13 & 70.9 & 4.6 \\
\hline
\end{tabular}

Table 6. Parameters for cesium ions elution-CT169.

\begin{tabular}{cccc}
\hline Cycle No. & $\mathbf{O Z}_{\mathbf{3}}$ & $\mathbf{O Z}_{\mathbf{4}}$ & $\boldsymbol{W}_{\text {Cs }}{ } \%$ \\
\hline I & 4 & 6 & 98.3 \\
II & 4 & 6 & 99.6 \\
III & 4 & 6 & 99.7 \\
\hline
\end{tabular}

Results of crystallisation tests are presented in Table 7. It was found that over $80 \%$ efficiency of cesium perrhenate crystallisation may be achieved when cesium concentration in a solution is higher than $5.0 \mathrm{~g} / \mathrm{dm}^{3} \mathrm{Cs}$. Impurity contents before and after purification are shown in Tables 8 and 9 , respectively. The proposed two-step crystal purification method-with $50 \mathrm{~cm}^{3} 10 \%$ aq. $\mathrm{H}_{2} \mathrm{O}_{2}$ solution, followed by $20 \mathrm{~cm}^{3}$ acetone washing-allowed for obtaining nanocrystalline cesium perrhenate containing stoichiometric amounts of cesium and rhenium (i.e., $34.7 \% \mathrm{Cs}$ and $48.6 \%$ Re and $<2 \mathrm{ppm}$ $\mathrm{Bi}_{;}<3$ ppm Zn; $<2$ ppm As; $<10$ ppm Ni; $<3$ ppm Mg; $<5$ ppm Cu; $<2$ ppm Na; $<5$ ppm Ca; $<3$ ppm $\mathrm{Fe} ;<5 \mathrm{ppm} \mathrm{Mo} ;<5 \mathrm{ppm} \mathrm{Pb} ;<10 \mathrm{ppm} \mathrm{K}$ ). XRD analysis of the crystals (Figure 7) proved that cesium perrhenate was prepared. 


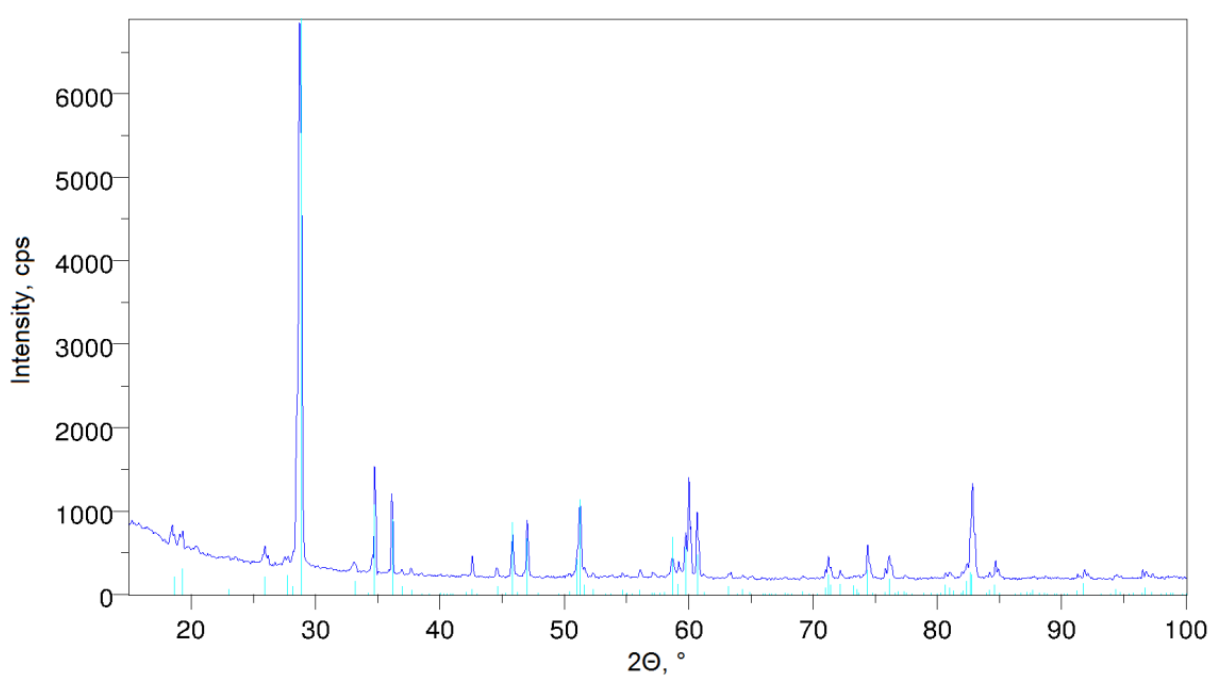

Figure 7. X-ray powder diffraction (XRD) patterns of cesium perrhenate crystals. (dark blue-sample pattern; light blue-database data).

Table 7. Results of $\mathrm{CsReO}_{4}$ crystallisation tests.

\begin{tabular}{|c|c|c|c|c|c|c|c|}
\hline $\begin{array}{l}\text { Test } \\
\text { No. }\end{array}$ & $\begin{array}{c}c_{0 K C s} \\
\left(\mathrm{~g} / \mathrm{dm}^{3}\right)\end{array}$ & $\begin{array}{c}c_{0 K R e} \\
\left(\mathrm{~g} / \mathrm{dm}^{3}\right)\end{array}$ & $\begin{array}{l}\text { Crystallite } \\
\text { Size (nm) }\end{array}$ & $\begin{array}{l}\text { Crystals } \\
\text { Mass (g) }\end{array}$ & $X_{\mathrm{Cs}}(\%)$ & $X_{\operatorname{Re}}(\%)$ & $W_{\mathrm{KCsReO} 4}(\%)$ \\
\hline 1 & 0.8 & 56.0 & $-*$ & 1.10 & $-*$ & $-*$ & 31.8 \\
\hline 2 & 3.2 & 75.0 & 44 & 9.10 & 34.88 & 49.25 & 65.8 \\
\hline 3 & 5.2 & 85.0 & 40 & 18.00 & 34.80 & 48.89 & 80.1 \\
\hline 4 & 10.5 & 98.0 & 35 & 40.00 & 34.75 & 48.61 & 88.2 \\
\hline
\end{tabular}

* analysis not done due to crystal mass being too small; $c_{0 K C s}$ : concentration of cesium in a solution directed to crystallisation; $c_{0 \mathrm{KRe}}$ : concentration of rhenium in a solution directed to crystallisation; $X_{\mathrm{Cs}}$ : cesium content in crystals; $X_{\mathrm{Re}}$ : rhenium content in crystals; $W_{\mathrm{KCsReO}}$ : crystallisation efficiency (i.e., ratio of crystals' mass to theoretical mass calculated according to Cs content in a solution).

Table 8. Impurity contents in crystallised $\mathrm{CsReO}_{4}$.

\begin{tabular}{|c|c|c|c|c|c|c|c|c|c|c|c|c|}
\hline $\begin{array}{l}\text { Test } \\
\text { No. }\end{array}$ & $\begin{array}{c}\mathrm{Bi} \\
(\mathrm{ppm})\end{array}$ & $\begin{array}{c}\mathrm{Na} \\
(\mathrm{ppm})\end{array}$ & $\begin{array}{c}\text { As } \\
(\mathrm{ppm})\end{array}$ & $\underset{(\mathrm{ppm})}{\mathrm{Ni}}$ & $\underset{(\mathrm{ppm})}{\mathrm{Mg}}$ & $\underset{(\mathrm{ppm})}{\mathrm{Cu}}$ & $\begin{array}{c}\mathrm{Ca} \\
(\mathrm{ppm})\end{array}$ & $\begin{array}{c}\mathrm{Fe} \\
(\mathrm{ppm})\end{array}$ & $\underset{(\mathrm{ppm})}{\mathrm{Zn}}$ & $\begin{array}{c}\text { Mo } \\
(\mathrm{ppm})\end{array}$ & $\begin{array}{c}\mathrm{K} \\
(\mathrm{ppm})\end{array}$ & $\begin{array}{c}\mathrm{Pb} \\
(\mathrm{ppm})\end{array}$ \\
\hline 1 & & 50 & & 48 & 15 & & & 12 & 10 & & & \\
\hline 2 & $<2$ & 48 & $<2$ & 38 & 16 & $<5$ & $<5$ & 15 & 12 & $<5$ & $<10$ & $<5$ \\
\hline 3 & & 47 & & 50 & 12 & & & 20 & 15 & & & \\
\hline
\end{tabular}

Table 9. Impurity contents after purification.

\begin{tabular}{cccccc}
\hline & Ni (ppm) & Mg (ppm) & Na (ppm) & Fe (ppm) & Zn (ppm) \\
\hline No purification & 50 & 12 & 47 & 20 & 15 \\
$5 \% \mathrm{H}_{2} \mathrm{O}_{2}$ & 32 & 10 & 20 & 5 & 15 \\
$10 \% \mathrm{H}_{2} \mathrm{O}_{2}$ & $<10$ & 10 & 15 & $<3$ & 12 \\
acetone & 46 & 5 & 15 & 6 & 5 \\
$10 \% \mathrm{H}_{2} \mathrm{O}_{2}+$ acetone & $<10$ & $<3$ & $<2$ & $<3$ & $<3$ \\
\hline
\end{tabular}

\subsection{Scheme of the Developed Technology}

The results of the experiments allowed the development of a technological scheme to produce high-purity nanocrystalline cesium perrhenate, which is patent-pending [32].

The developed method of anhydrous cesium perrhenate preparation is composed of eight technological blocks (Figure 8). Firstly, aqueous cesium nitrate solutions are directed to cesium 
sorption stage, where the solution is transferred through a CT169 ion-exchange resin bed placed inside an ion-exchange column. Sorption is performed down the columns at room temperature. The solution-bed contact time is up to $60 \mathrm{~min}$. After the sorption stage the ion-exchange resin is washed using demineralised water, while post-sorption and post-washing solution streams are connected and directed to the initial solution preparation. The washed column containing the bed with sorbed cesium is eluted downward with aqueous perrhenic acid solution at room temperature, so the eluent-resin contact time is above $120 \mathrm{~min}$. The eluate is collected as a single portion and directed to concentration and crystallisation, while the eluted bed is washed with demineralised water. The post-washing solutions obtained after elution are divided into two portions-the first one is connected with the solution directed to the concentration stage, while the second one, together with mother liquors and post-purification solutions, is directed to waste management. The solution obtained after the second part of elution, containing more than $5.0 \mathrm{~g} / \mathrm{dm}^{3} \mathrm{Cs}$, is directed to concentration and crystallisation. The concentration stage is carried out at a temperature not exceeding $80^{\circ} \mathrm{C}$, preferably under vigorous stirring. Then, the solution is quenched and cesium perrhenate is crystallised. The crystals are filtered from a solution and washed with $10 \%$ aq. hydrogen peroxide solution and anhydrous acetone. Finally, the prepared cesium perrhenate crystals $(\leq 45 \mathrm{~nm})$ are dried at $120{ }^{\circ} \mathrm{C}$ until constant mass.

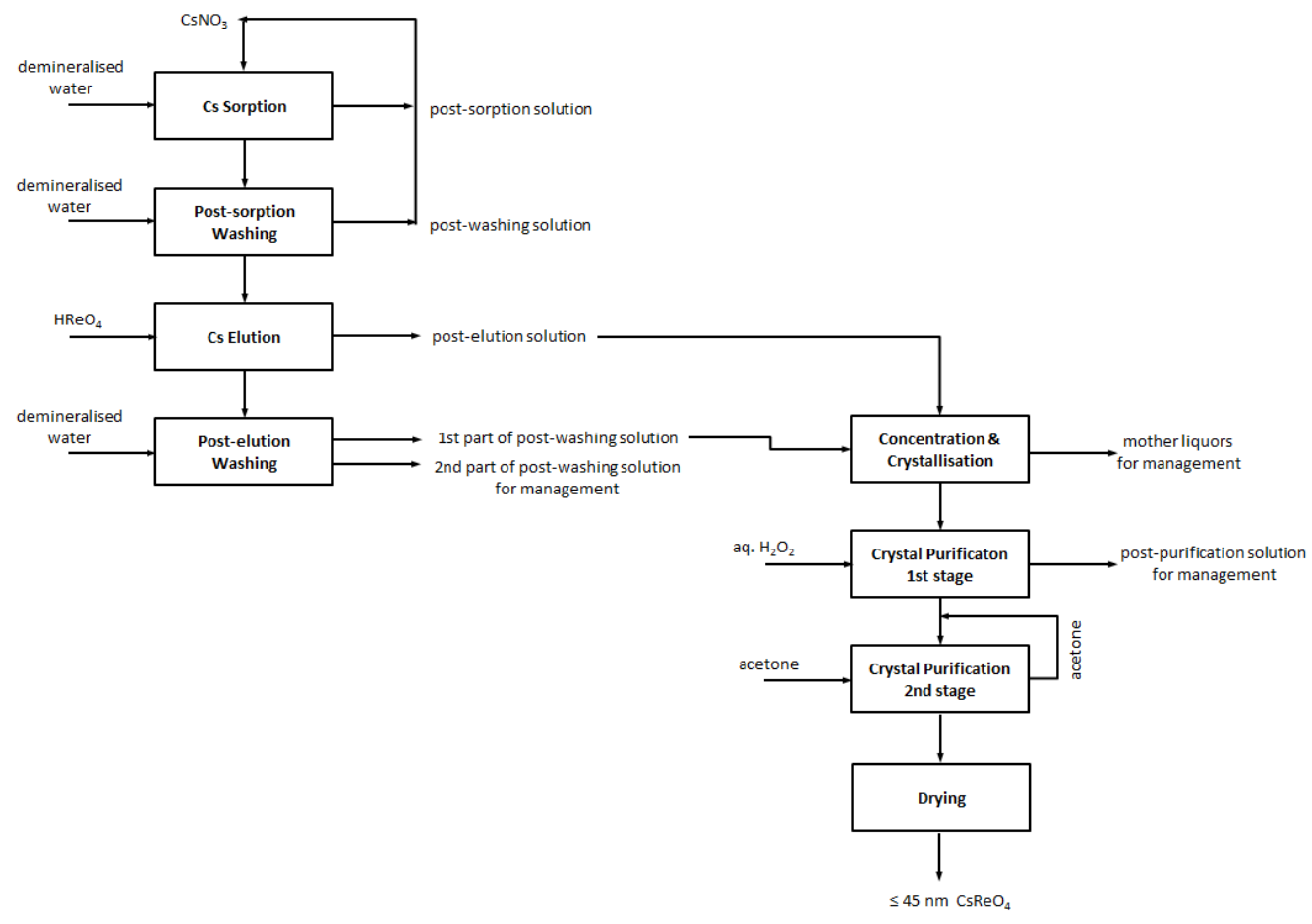

Figure 8. Technological scheme of anhydrous nanocrystalline cesium perrhenate preparation.

The proposed method, and its process conditions, allow the preparation of anhydrous nanocrystalline $(\leq 45 \mathrm{~nm}$ ) cesium perrhenate of stoichiometric composition in a reproducible way (Table 10).

Table 10. Separation and purification of cesium perrhenate.

\begin{tabular}{ccccc}
\hline $\begin{array}{c}\text { Volume of Solution } \\
\text { Sent for Concentration }\end{array}$ & $\begin{array}{c}\text { Cs Concentration in a Solution } \\
\text { for Concentration }\end{array}$ & $\begin{array}{c}\text { Re Concentration in a } \\
\text { Solution for Concentration }\end{array}$ & $\begin{array}{c}\text { Crystallite } \\
\text { Size }\end{array}$ & $\begin{array}{c}\text { Crystallisation } \\
\text { Efficiency }\end{array}$ \\
\hline $\mathbf{c m}^{3}$ & $\mathbf{g} / \mathbf{d m}^{\mathbf{3}}$ & $\mathbf{g} / \mathbf{d m}^{\mathbf{3}}$ & $\mathbf{n m}$ & - \\
\hline 300 & 0.8 & 56.0 & - & \\
300 & 3.2 & 75.0 & 44 & 85.5 \\
300 & 5.2 & 85.0 & 40 & 80.2 \\
300 & 10.5 & 98.0 & 85.6 \\
\hline
\end{tabular}




\section{Conclusions}

It was found that the ion-exchange method with strongly acidic cation-exchange resin (CT169) was able to produce extra-pure anhydrous cesium perrhenate with crystallite size $<45 \mathrm{~nm}$ and with the following composition: $34.7 \% \mathrm{Cs} ; 48.6 \% \mathrm{Re} ;<2$ ppm Bi; $<3$ ppm Zn; $<2$ ppm As; $<10$ ppm Ni; $<3$ ppm $\mathrm{Mg} ;<5$ ppm Cu; $<2$ ppm Na; $<5$ ppm Ca; $<3$ ppm Fe; $<5$ ppm Mo; $<5$ ppm Pb; $<10$ ppm K. Using this method, $2.0 \mathrm{~kg}$ cesium perrhenate was prepared.

Acknowledgments: This work was supported by The Polish State Committee for Scientific Research, Project No. PBS2/A5/40/2014 and by own funds.

Author Contributions: K.L.S. and G.B. conceived and designed the experiments; K.L.S. and J.M. performed the experiments; K.L.S., G.B. and M.D. analysed the data; K.L.S. and M.C. wrote the paper.

Conflicts of Interest: The authors declare no conflict of interest.

\section{References}

1. Roskil Information Services. Economics of Caesium and Rubidium (Reports on Metals \& Minerals); Roskill Information Services: London, UK, 1984; p. 51.

2. Leddicotte, G.W. The Radiochemistry of Rhenium; Subcomitee on Radiochemistry National Academy of Sciences-National Research Council: Washington, DC, USA, 1961.

3. Roskil. Rhenium: Market Outlook to 2020; Roskill Information Services: London, UK, 2010; p. 51.

4. Ryashentseva, M.A. Rhenium-containing catalysts in reactions of organic compounds. Russ. Chem. Rev. 1998, 67, 157-177. [CrossRef]

5. Kuninobu, Y.; Takai, K. Organic Reactions Catalyzed by Rhenium Carbonyl Complexes. Chem. Rev. 2011, 111, 1938-1953. [CrossRef] [PubMed]

6. Shugurov, S.M.; Lopatin, S.I. Thermochemical Study of Gaseous Salts of Oxygen-Containing Acids: XXIV.1 Polymers of Alkali Metals Perrenates. Russ. J. Gen. Chem. 2008, 78, 1882-1888. [CrossRef]

7. Range, K.-J.; Rögner, P.; Heyns, A.M.; Prinsloo, L.C. An X-Ray, Raman and IR Study of $\alpha$-CsReO ${ }_{4}$, the High-Temperature Modification of Cesium Perrhenate. Z. Naturforsch. 1992, 47b, 1513-1520. [CrossRef]

8. Rögner, P.; Range, K.-J. The Crystal Structure of $\beta$-CsReO 4 , the Room-Temperature Modification of Cesium Perrhenate. Z. Naturforsch. 1993, 486, 685-687. [CrossRef]

9. Smith, W.T.; Long, S.H. The Salts of Perrhenic Acid. I. The Alkali Metals and Ammonium. J. Am. Chem. Soc. 1948, 70, 354-356. [CrossRef]

10. Lukas, W.; Chatillon, C.; Alliber, M. The thermodynamic activity of $\mathrm{LiReO}_{4}$ in the $\mathrm{LiReO}_{4}-\mathrm{CsReO}_{4}$ system as determined by mass spectrometry. J. Less-Common Met. 1979, 66, 211-217. [CrossRef]

11. Arthers, S.A.; Beattie, I.R.; Gomme, R.A.; Jones, P.J.; Ogden, J.S. Matrix Isolation Studies on Alkali Metal Perrhenates: The Shape and Vibrational Assignments of Caesium Perrhenate, $\mathrm{CsReO}_{4}$. J. Chem. Soc. Dalton Trans. 1983, 7, 1461-1464. [CrossRef]

12. Hurd, L.C. The Determination of Rhenium. Ind. Eng. Chem. Anal. Ed. 1936, 8, 112-114. [CrossRef]

13. Process for Electroplating Magnetic Films for High Density Recording. Available online: https:// docs.google.com/viewer?url=patentimages.storage.googleapis.com/pdfs/US3704211.pdf (accessed on 23 December 2016).

14. Alkylene Oxide Catalysts Having Enhanced Activity and/or Stability. Available online: https:// docs.google.com/viewer?url=patentimages.storage.googleapis.com/pdfs/US5504053.pdf (accessed on 23 December 2016).

15. Kleppa, O.J.; Meschel, S.V. Thermochemistry of anion mixture in simple fused salt systems. II. Solutions of some salts of $\mathrm{Mo}_{4}{ }^{-}$and $\mathrm{Mo}_{4}{ }^{-2}$ anions in the corresponding alkali nitrates. J. Phys. Chem. 1963, 67, 2750-2753. [CrossRef]

16. Kawai, T.; Goto, H.; Yamazaki, Y.; Ishikawa, T. Metathesis of n-alkenes over a $\mathrm{CsNO}_{3}-\mathrm{Re}_{2} \mathrm{O}_{7}-\mathrm{Al}_{2} \mathrm{O}_{3}$ catalyst. J. Mol. Catal. 1988, 46, 157-172. [CrossRef]

17. Process for Converting C5 Olefinic Cuts by Metathesis Using a Catalyst Based on Rhenium and Cesium. Available online: https://docs.google.com/viewer?url=patentimages.storage.googleapis.com/ pdfs/US6235958.pdf (accessed on 23 December 2016). 
18. Leszczyńska-Sejda, K.; Benke, G.; Chmielarz, A.; Anyszkiewicz, K.; Satora, W.; Kozub, K. Hydrometallurgical Methods for Production of $\mathrm{Ni}\left(\mathrm{ReO}_{4}\right)_{2}$ and $\mathrm{Co}\left(\mathrm{ReO}_{4}\right)_{2}$. In Proceedings of the European Metallurgical Conference EMC 2013, Weimar, Germany, 23-26 June 2016; Eicke, S., Hahn, M., Eds.; GDMB: Clausthal-Zellerfeld, Germany, 2013; pp. 885-898.

19. Duignan, M.R.; Nash, C.A. Removal of Cesium from Savannah River Site Waste with Spherical Resorcinol Formaldehyde Ion Exchange Resin: Experimental Tests. Sep. Sci. Technol. 2010, 45, 1828-1840. [CrossRef]

20. Awual, M.R.; Suzuki, S.; Taguchi, T.; Shiwaku, H.; Okamoto, Y.; Yaita, T. Radioactive cesium removal from nuclear wastewater by novel inorganic and conjugate adsorbents. Chem. Eng. J. 2014, 242, 127-135. [CrossRef]

21. Awual, M.R. Ring size dependent crown ether based mesoporous adsorbent for high cesium adsorption from wastewater. Chem. Eng. J. 2016, 303, 539-546. [CrossRef]

22. Awual, M.R.; Miyazaki, Y.; Taguchi, T.; Shiwaku, H.; Yaita, T. Encapsulation of cesium from contaminated water with highly selective facial organic-inorganic mesoporous hybrid adsorbent. Chem. Eng. J. 2016, 291, 128-137. [CrossRef]

23. Awual, M.R.; Yaitaa, T.; Taguchi, T.; Shiwaku, H.; Suzuki, S.; Okamoto, Y. Selective cesium removal from radioactive liquid waste by crownether immobilized new class conjugate adsorbent. J. Hazard. Mater. 2014, 278, 227-235. [CrossRef] [PubMed]

24. Lai, Y.C.; Chang, Y.R.; Chen, M.L.; Lo, Y.K.; Lai, J.Y.; Lee, D.J. Poly(vinyl alcohol) and alginate cross-linked matrix with immobilized. Bioresour. Technol. 2016, 214, 192-198. [CrossRef] [PubMed]

25. Leszczyńska-Sejda, K.; Benke, G.; Anyszkiewicz, K.; Chmielarz, A. Metylotrioxorhenium(VII) as catalyst of important organic reactions. Przem. Chem. 2008, 87, 1102-1105.

26. Hermann, W.; Kratzer, R.M.; Fisher, R.W. Alkylrhenium Oxides from Perrhenates: A New, Economical Access to Organometallic Oxide Catalysts. Angew. Chem. Int. Ed. Engl. 1997, 36, 2652-2654. [CrossRef]

27. Kojima, R.; Enomoto, H.; Muhler, M.; Aika, K. Cesium-promoted rhenium catalysts supported on alumina for ammonia synthesis. Appl. Catal. A 2003, 246, 311-322. [CrossRef]

28. U.S. Nuclear Regulatory Commision. § 30.71 Schedule B; United States Nuclear Regulatory Commission: North Bethesda, MD, USA, 2007.

29. Leszczyńska-Sejda, K.; Benke, G.; Anyszkiewicz, K. Opracowanie metod otrzymywania kwasu nadrenowego $\mathrm{z}$ nadrenianu amonu. Przem. Chem. 2006, 85, 847.

30. Leszczyńska-Sejda, K.; Benke, G.; Chmielarz, A.; Krompiec, S.; Michalik, S.; Krompiec, M. Synthesis of perrhenic acid using ion exchange method. Hydrometallurgy 2007, 89, 289-296. [CrossRef]

31. Leszczyńska-Sejda, K.; Benke, G.; Anyszkiewicz, K. Zastosowanie jonitów do sorpcji jonów amonowych z wodnych roztworów renianu(VII) amonu. Przem. Chem. 2008, 87, 289-295. (In Polish)

32. Leszczyńska-Sejda, K.; Benke, G.; Malarz, J.; Drzazga, M.; Ciszewski, M. Sposób Wytwarzania Bezwodnego Renianu(VII) Cezu. Polish Patent Application P.419867, 20 December 2016.

(C) 2017 by the authors. Licensee MDPI, Basel, Switzerland. This article is an open access article distributed under the terms and conditions of the Creative Commons Attribution (CC BY) license (http:/ / creativecommons.org/licenses/by/4.0/). 